\title{
Effect of Concentrations and Frequency of Iron Foliar Application on Yield and Leaves Mineral Content of Valencia Orange Tree Ibrahim, A. M. ${ }^{1}$ and O. R. Abd Elkawy ${ }^{2}$ \\ ${ }^{1}$ Horticultural Research Institute, Agricultural Research Centre, Giza, Egypt. \\ ${ }^{2}$ Department of Soil and Water Sciences, Faculty of Agriculture, Alx., Univ.,
}

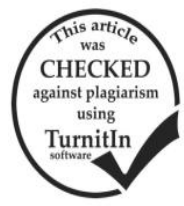

\section{ABSTRACT}

A field trial was made to study the effect of spraying different Iron concentrations with different dates on yield and mineral contents of mature Valencia orange trees grown in sandy soil at Salhia area in Sharkia Governorate. It is advisable to spray the Valencia orange trees under the similar conditions with chelated iron at $0.7 \%$ on March. Nitrogen and phosphorous contents in leaves of sprayed trees slightly decreased as the rate of chelated iron increased, whereas potassium content decreased, whereas Iron content generally increased.

\section{INTRODUCTION}

Under alkaline conditions, iron is precipitated as insoluble ferric hydroxide (Basiouny and Leonard, 1970). Soils containing free calcium carbonate having a high $\mathrm{pH}$ are therefore potentially iron deficient (Hilgeman, 1955). High concentrations of other elements can also give rise to iron deficiency such as zinc, manganese, and phosphorus (Chapman, 1960).

Efforts to correct Fe deficiency chlorosis in citrus trees by application of foliar sprays containing $\mathrm{Fe}$ have generally been unsuccessful (Guest and Chaman, 1949; Wallihan and Embleton, (1961) and Wallihan et al., (1954). Response usually consists of small isolated green spots, indicating that absorption of Fe is strongly localized and that little movement of Fe occurs within the tissues. Numerous tests with different additives and spray procedures have heretofore failed to bring about significant improvement in response (Wallihan et al., 1964). Primo et al., (1970) reported that foliar treatments with $1 \%$ solution of $\mathrm{Fe}$ EDDHA eliminated deficiency symptoms in orange trees and increased the iron content of the leaves to normal levels.

Iron deficiency chlorosis occurred on approximately $30 \%$ of cultivated land area worldwide (Chen and Barak, 1982) and led to nutritional disorder frequently in many fruit trees grown on calcareous soils with a high $\mathrm{pH}$. The high $\mathrm{HCO} 3$ concentration and $\mathrm{pH}$ in calcareous soil are two main factors responsible for low $\mathrm{Fe}$ availability in soil and low Fe efficiency in plant (Mengel., 1994). Iron chlorosis is a more complex phenomenon in fruit trees than in annual crops (Tagliavini et al., 2000), because fruit trees bearing a large amount of fruits each year are more likely to suffer severe chlorosis in the following year chlorosis occurs more frequently in spring when rainfalls increase soil bicarbonate concentration in this period of intense Fe demand (Boxma, 1972); and Fe transport needs a longer distance in fruit trees to reach the canopy than in annual crops (Tagliavini and Rombola, 2001). According to the hypothesis of Mengel (1994), iron deficiency chlorosis in calcareous soils was caused by restriction of Fe translocation from the root apoplast into the root symplast and from leaf apoplast into the leaf symplast. Therefore, the leaf total Fe concentration can not accurately reflects the Fe nutritional status in fruit trees and crops on calcareous soils (Pestana et al., 2003).

The objective of the present study was to test different concentrations and spraying dates of chelated iron application in relation to Valencia orange trees performance in sandy soils.

\section{MATERIALS AND METHODS}

The current experiment was implemented in 2016 and 2017 seasons on mature 15 - years old Valencia orange, budded on sour orange rootstock at Elsalm farm, Salhia area in Sharkia Governorate. The trees were exhibiting various types of iron deficiency as shown in Table (1).

Table 1. Concentration of some nutrients in soil and leaves of non-fruiting terminals of the experimental orchard.

\begin{tabular}{lccc}
\hline Elements & $\begin{array}{c}\text { Soil } \\
\text { sample }\end{array}$ & $\begin{array}{c}\text { Leaf } \\
\text { sample }\end{array}$ & $\begin{array}{c}\text { Satisfactory } \\
\text { inleaves inrange }\end{array}$ \\
\hline Boron (ppm) & 0.7 & - & $30-100 \mathrm{ppm}$ \\
Copper (ppm) & 6.5 & 7.2 & $5-15 \mathrm{ppm}$ \\
Iron (ppm) & 38 & 40 & $50-150 \mathrm{ppm}$ \\
Manganese (ppm) & 36 & 39 & $25-100 \mathrm{ppm}$ \\
Zinc (ppm) & 8 & 40 & $25-100 \mathrm{ppm}$ \\
Nitrogen (\%) & 1.91 & 2.11 & $2.2-2.7 \%$ \\
Phosphorous (\%) & 7 & 0.12 & $0.10-017 \%$ \\
Potassium (\%) & 1.10 & 1.36 & $0.7-1.5 \%$ \\
Calcium & 1.66 & 3.79 & $2.6-5.0 \%$ \\
Magnesium (\%) & 1.09 & 0.29 & $0.3-0.6 \%$ \\
\hline
\end{tabular}

The experiment was established on a sandy texture soil with $\mathrm{pH}$ values ranged from 7.2 to 7.9 . Boron concentration in the soil $(0.7 \mathrm{ppm})$ was in the range considered as optimum, while concentrations of soil extractable phosphorous, potassium, calcium, magnesium (7, 1.1, 1.6 and $1.09 \%$, respectively) were very high as well as the soil micronutrients concentrations (FAO 2006).

The experimental design was split plot with three trees in each sub treatment unit, replicated three times. The details of the treatments were as follows:

Main treatment (levels of chelated iron): control foliar, sprays at $0.5,0.7$, and $1.0 \%$.

Sub treatments (number of applications): sprays in March (T1) just before blooming, March and June (T2) after fruit set, and March, June, and September (T3).

A guard row of trees around every sub-plot and in between the replications was maintained. The chelated $\mathrm{Fe}$ was technical sodium ethylene diamine (Ohydroxyphenylacetate) containing $6.0 \% \mathrm{Fe}$ equivalent to $8.5 \%$ to $8.5 \% \mathrm{Fe}_{2} \mathrm{O}_{3}$. Urea (urena contained thes 0.25 percent biuret) was added at the rate of $10 \mathrm{~g}$ per litre of water in order to enhance the absorption of the sprayed nutrient (Wallace, 1966 and Labanuskas et al., 1969). The spraying was done by using a 10-litre capacity hand sprayer.

All trees received ammonium sulphate, calcium superphosphate, and potassium sulphate added at a rate of $1000 \mathrm{~g} \mathrm{~N}, 125 \mathrm{~g} \mathrm{P}_{2} \mathrm{O}_{5}$ and $140 \mathrm{gK}_{2} \mathrm{O} /$ tree/year in 3 equal applications (March, May, and July) as recommended and adopted in Elsalm farm, Salhia area in Sharkia Governorate. 
The pest control program was carried out in accordance with the farm program

Yield per tree at harvest time during early March was estimated. leaf samples were taken in mid-October from non-fruiting spring tagged flushes as recommended by Chapman (1960).

The leaf samples were cleaned from the soil with a wet cloth, washed with $0.1 \mathrm{~N} \mathrm{HCI}$, then with distilled water, dried at 65 to $70^{\circ} \mathrm{C}$ until the fixed weight. Dry weight was weighed and processed for chemical analysisin order to estimate the content of the leaves of some nutrients under study

Nitrogen was determined by semi micro kjeldahl method according to Ranker (1972) whereas the rest of the elements was determined by the emission Spectrograph method (Wallace, 1971).

All the data were statistically analyzed according to the methed described by Cochroan and Cox (1957).

\section{RESULTS AND DISCUSSION}

Yield:

It is clear from the average data shown in table (2) that foliar sprays with chelated iron resulted in an increase in yield over the control. This increase was significant with treatment where trees were sprayed with chelated iron at $0.7 \%$ in the both seasons.

As regard to the number of applications, it appeared that one application in March (T1) proved to be the most

effective and than application in March and June (T2), and the same treatment was significant than treatment sprayed with chelated iron for three times (T3).

The interaction between rate and number of applications had statistical significant effect on yield weight of Valencia orang. This means that both the two factors created significant effects on yield. These results are in accordance with the findings of Saad-Alla et al. (1981) on Valencia orange and Sweidan et al. (1982) on Washington navel orange planted in sandy soil. They found that foliar sprays with some iron compound led to an increase in yield. On the other hand, Wallihan and Garber (1966) observed that when concentration of $\mathrm{Fe}$ in spring cycle leaves of navel orange trees was below $30 \mathrm{ppm}$ in September, the production of fruit was less than when Fe-concentration exceeded $30 \mathrm{ppm}$. As the Fe content decreased below this value, fruit production progressively declined reaching essentially zero at $12 \mathrm{ppm}$ of Fe. The decrease in yield was due to a fewer fruits being matured. Huang et al, (2012) Effects of Fe-EDDHA application on iron chlorosis of citrus trees and comparison of evaluations on nutrient balance with three approaches. Loupassaki, et al., (1997) correction by different methods. The citrus yield was mainly affected by $\mathrm{Fe}$, whereas fruit quality was improved by $\mathrm{Zn}$. The application of Fe-EDDHA alone could induce $\mathrm{Zn}$ deficiency, so the co-application of Fe-EDDHA and $\mathrm{Zn}$ fertilizer was useful for obtaining higher yield

Table 2. Effect of chelated iron spray on yield weight per tree $(\mathrm{kg})$ of Valencia orange trees

\begin{tabular}{|c|c|c|c|c|c|c|c|c|c|c|c|c|}
\hline \multirow{3}{*}{$\begin{array}{l}\text { Chelated iron } \\
(\%)\end{array}$} & \multicolumn{12}{|c|}{ No. of applications } \\
\hline & \multicolumn{4}{|c|}{2016} & \multicolumn{4}{|c|}{2017} & \multicolumn{4}{|c|}{ Mean of two seasons } \\
\hline & T1 & $\mathbf{T 2}$ & T3 & Av. & T1 & T2 & T3 & Av. & T1. & $\mathbf{T 2}$ & T3. & Av. \\
\hline Control & 49.2 & 50.9 & 56.3 & 52.1 & 51.3 & 45.2 & 51.2 & 49.2 & 50.3 & 48.0 & 53.7 & 50.7 \\
\hline 0.5 & 58.8 & 66.7 & 49.5 & 58.3 & 65.6 & 70.9 & 53.7 & 63.4 & 62.2 & 68.8 & 51.6 & 60.9 \\
\hline 0.7 & 74.5 & 63.0 & 67.8 & 68.4 & 76.0 & 70.1 & 68.5 & 71.5 & 75.3 & 66.5 & 68.1 & 70.0 \\
\hline 1.0 & 59.7 & 56.9 & 49.9 & 55.5 & 69.5 & 60.8 & 58.8 & 63.0 & 64.6 & 58.8 & 54.3 & 59.2 \\
\hline Mean & 60.5 & 59.4 & 55.9 & & 65.6 & 61.7 & 58.1 & & 63.1 & 60.5 & 56.9 & \\
\hline 1.S.D. (0.05): & \multirow{2}{*}{\multicolumn{4}{|c|}{7.2}} & \multirow{2}{*}{\multicolumn{4}{|c|}{9.6}} & \multirow{2}{*}{\multicolumn{4}{|c|}{10.9}} \\
\hline Levels of iron spray (A) & & & & & & & & & & & & \\
\hline No. of application (B) & \multicolumn{4}{|c|}{3.1} & \multicolumn{4}{|c|}{5.2} & \multicolumn{4}{|c|}{4.1} \\
\hline Interaction: (A) $\times(\mathrm{B})$ & \multicolumn{4}{|c|}{2.6} & \multicolumn{4}{|c|}{3.8} & \multicolumn{4}{|c|}{5.9} \\
\hline
\end{tabular}

Zekri and Obreza (2009) recorded yield of ironsprayed and non-sprayed plant nutrients for citrus trees cultivars grown on high $\mathrm{pH}$ calcareous soil. Fe-EDDHA resulted in a rapid increase in leaf chlorophyll and, in the same season that the treatment took place, both fruit size and tree yield increased observably in kiwi fruit (Loupassaki etal.,1997) and strawberry Moreover, some studies have reported that $\mathrm{Zn}$ application benefitted vegetative growth, yield and fruit quality in alkaline soils . Srivastava and Singh (2009), proved that tomatoes planted in a nutrient solution with standard or high Mn content exhibited better vegetative growth and fruit yield than those planted in a low Mn nutrient solution. However, most of the research has focused on the lack of a single element to carry on the fertilization treatments. Given that there is a synergistic effect or antagonism for microelement absorption in citrus trees, alarge number of individual elements may affect the absorption of other elements. Therefore, single microelement fertilizer applications cannot comprehensively improve crops nutrient status in calcareous soil.

$\mathrm{Fe}, \mathrm{Zn}$ and $\mathrm{Mn}$ are essential microelements of higher plants $\mathrm{Fe}$ catalyzes the production of chlorophyll and is involved in some respiratory and photosynthetic enzyme systems. Fe deficiency inhibits vegetative growth and the formation of flower buds, affecting the number of buds and fruit sets in citrus on calcareous soils Zekri and Obreza, (2003).

\section{Mineral content:}

The results obtained in Table (3) (a, b, c) elucidate the leaves from trees sprayed with chelated Iron containing more, $\mathrm{N}, \mathrm{P}$, and $\mathrm{K}$ than the control. The increment in potassium content was significant as the rate of chelated iron increased, whereas the values of phosphorus content were converse. The increment in potassium content in both the two seasons (2016 and 2017) were insignificant.

Comparing the efficiency application number, in general, data showed that three applications (March, June, and September) were the most effective values for increment the concentration of nitrogen and potassium contents. The increment in nitrogen content was significant only in the first season, while the values of potassium content showed some variation in both two seasons. The phosphorus content showed some fluctuations, with no definite effect for number of application. Sideris and Young (1946), obtained increase 
nitrogen content in the leaves of pineapple plant in the culture supplied with iron than no iron. On the other hand, Nawar (1978), observed that spraying Washington navel orange with chelated iron at different dates tended to decrease the nitrogen content in leaves than the control, whereas phosphorus content had the contrary trend.

Table 3. a. Leaf concentration of $\mathbf{N}$ in Valencia orange sprayed with chelated iron in both 2016 and 2017 seasons.

\begin{tabular}{|c|c|c|c|c|c|c|c|}
\hline & \multicolumn{6}{|c|}{$\mathbf{N \%}$} & \multirow[b]{2}{*}{ Av. } \\
\hline & \multirow{2}{*}{$\begin{array}{r}1 \\
2016 \\
\end{array}$} & \multirow{2}{*}{$\begin{array}{l}1 \\
2017\end{array}$} & \multicolumn{2}{|c|}{ T2 } & \multirow{2}{*}{\multicolumn{2}{|c|}{$\begin{array}{c}\text { T3 } \\
20162017\end{array}$}} & \\
\hline & & & 2016 & 2017 & & & 20162017 \\
\hline $\begin{array}{l}\text { Chelated } \\
\text { iron (\%) }\end{array}$ & 2.08 & 2.13 & 2.10 & 2.17 & 2.15 & 2.10 & $2.11 \quad 2.13$ \\
\hline 0.5 & 2.53 & 2.61 & 2.57 & 2.55 & 2.71 & 2.68 & 2.602 .61 \\
\hline 0.7 & 2.57 & 2.48 & 2.54 & 2.60 & 2.78 & 2.73 & $2.63 \quad 2.61$ \\
\hline 1.0 & 2.38 & 2.44 & 2.51 & 2.39 & 2.56 & 2.48 & $2.48 \quad 2.44$ \\
\hline Mean & 2.39 & 2.42 & 2.43 & 2.43 & 2.55 & 2.50 & $2.46 \quad 2.45$ \\
\hline \multicolumn{7}{|c|}{ LSD (0.05): } & $0.16 \quad 0.20$ \\
\hline \multicolumn{7}{|c|}{ Levels of iron spray (A) } & $0.09 \quad 0.14$ \\
\hline \multicolumn{7}{|c|}{ No. of applications (B) } & $0.13 \quad 0.12$ \\
\hline
\end{tabular}

Table 3. b. Leaf concentration of $P$ in Valencia orange sprayed with chelated iron in both 2016 and 2017 seasons.

\begin{tabular}{|c|c|c|c|c|c|c|c|c|}
\hline & & & P\% & & & & & \\
\hline Chelated & & & $\mathbf{T}$ & 2 & & 3 & & v. \\
\hline iron (\%) & 2016 & 2017 & 2016 & 2017 & 2016 & 2017 & 2016 & 2017 \\
\hline Control & 0.27 & 0.32 & 0.25 & 0.28 & 0.26 & 0.26 & 0.26 & 0.29 \\
\hline 0.5 & 0.44 & 0.42 & 0.48 & 0.51 & 0.46 & 0.48 & 0.46 & 0.47 \\
\hline 0.7 & 0.34 & 0.38 & 0.41 & 0.36 & 0.39 & 0.36 & 0.38 & 0.37 \\
\hline 1.0 & 0.33 & 0.38 & 0.36 & 0.31 & 0.28 & 0.31 & 0.33 & 0.33 \\
\hline Mean & 0.35 & 0.35 & 0.36 & 0.37 & 0.35 & 0.35 & 0.36 & 0.36 \\
\hline $\mathrm{LSD}(0.05$ & & & & & & & N.S. & N.S. \\
\hline Levels of $\mathrm{i}$ & spras & (A) & & & & & ----- & ----- \\
\hline No. of app & tions & (B) & & & & & & \\
\hline Interaction & A) $\times($ & & & & & & & \\
\hline
\end{tabular}

Table 3. c. Leaf concentration of $K$ in Valencia orange sprayed with chelated iron in both 2016 and 2017 seasons.

\begin{tabular}{|c|c|c|c|c|c|c|c|c|}
\hline & & & $\mathbf{K}^{\mathbf{0}}$ & & & & & \\
\hline Chelated & & 1 & & 2 & & T3 & $\mathbf{A}$ & \\
\hline iron $(\%)$ & 2016 & 2017 & 2016 & 2017 & 2016 & 2017 & 2016 & 2017 \\
\hline Control & 1.83 & 1.97 & 1.85 & 1.91 & 2.01 & 1.94 & 1.90 & 1.94 \\
\hline 0.5 & 2.01 & 2.03 & 2.04 & 2.07 & 2.05 & 2.04 & 2.03 & 2.05 \\
\hline 0.7 & 2.07 & 2.09 & 2.11 & 2.08 & 2.11 & 2.07 & 2.10 & 2.08 \\
\hline 1.0 & 2.11 & 2.09 & 2.13 & 2.14 & 2.12 & 2.09 & 2.12 & 2.11 \\
\hline Mean & 2.01 & 2.05 & 2.03 & 2.05 & 2.07 & 2.04 & & \\
\hline LSD $(0.05$ & & & & & & & 0.33 & 0.24 \\
\hline Levels of & n spra & $y(A)$ & & & & & 0.25 & 0.11 \\
\hline $\begin{array}{l}\text { No. of app } \\
\text { Interaction }\end{array}$ & A) $x$ & $\begin{array}{l}\text { (B) } \\
\text { (B) }\end{array}$ & & & & & 0.17 & 0.13 \\
\hline
\end{tabular}

Foliar application of chelated iron during the two seasons raised the iron content of Valencia orange leaves. Table 4 these findings were in line with those obtained by Wallace (1966) and Sweidan et al., (1982), on Washington navel at el-Tahreer Province.

They found that spraying the trees with iron caused an increase in the iron content of the leaves.

Regarding the number of applications, data in hand clearly showed that three applications (March, June, and September), were the most effective dates for applying iron sprays. Since the increments in the treatment were 5 and $2.26 \%$ than the sprays at March or on March and June treatment, respectively. In addition to the previously mentioned explanation for the high efficiency of applying nutrients in March.

Regarding Zinc, and manganese content, it was noticed from the obtained data as shown in Table (4) (a, b, c) that $\mathrm{Zn}$ and $\mathrm{Mn}$ contents were not affected by spraying chelated in the first season. The same treatment in the second season caused a marked reduction in both nutrients content. No doubt this could be due to the internal disturbance in the nutritional status of the leaves as the leaf iron concentration was greatly increased, specially in the second season, as a result of spraying the trees with iron for two consecutive years. In this respect, Wallace (1971), reported that iron interferes with the uptake and translocation of zinc in plants. However, he added, that the antagonism between iron and zinc was a matter of translocation rather than absorption. Similarly, Smith (1962) reported that the interference between iron and manganese may occur during the translocation process or at the site of utilization.

Table 4. a. Leaf concentration of Iron (ppm) in Velencia orange tree sprayed with chelated iron in both 2016 and 2017 seasons.

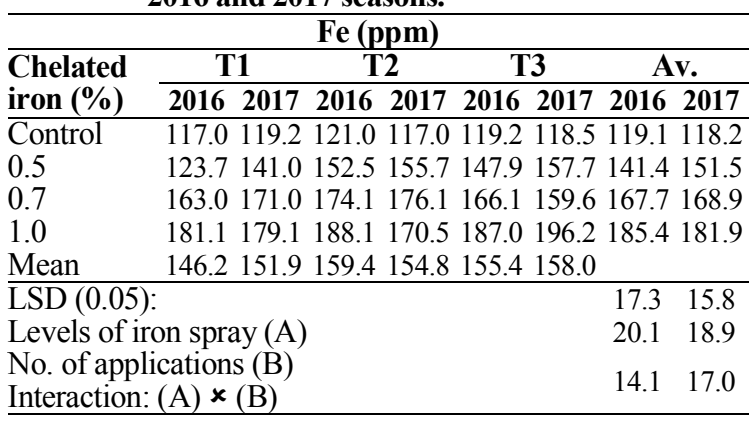

Table 4. b. Leaf concentration of Zinc (ppm) in Velencia orange tree sprayed with chelated iron in both 2016 and 2017 seasons.

\begin{tabular}{|c|c|c|c|c|c|c|c|c|}
\hline \multicolumn{9}{|c|}{ Zn (ppm) } \\
\hline \multirow{2}{*}{$\begin{array}{l}\text { Chelated } \\
\text { iron }(\%)\end{array}$} & \multicolumn{2}{|c|}{ T1 } & \multicolumn{2}{|c|}{ T2 } & \multicolumn{2}{|c|}{ T3 } & \multicolumn{2}{|c|}{ Av. } \\
\hline & 2016 & 2017 & 2016 & 2017 & 2016 & 2017 & 2016 & 2017 \\
\hline Control & 12.7 & 11.5 & 10.9 & 12.5 & 13.1 & 12.7 & 12.2 & 12.2 \\
\hline 0.5 & 11.7 & 9.3 & 10.9 & 9.2 & 12.7 & 8.7 & 11.8 & 9.0 \\
\hline 0.7 & 13.6 & 10.2 & 12.7 & 12.7 & 13.6 & 11.0 & 13.3 & 11.3 \\
\hline 1.0 & 11.7 & 11.0 & 9.3 & 11.7 & 14.0 & 9.3 & 11.7 & 10.6 \\
\hline Mean & 12.4 & 10.5 & 10.9 & 11.5 & 13.1 & 10.4 & & \\
\hline \multicolumn{7}{|c|}{$\operatorname{LSD}(0.05):$} & & 3.43 \\
\hline \multicolumn{7}{|c|}{ Levels of iron spray (A) } & 1.97 & 1.8 \\
\hline \multicolumn{7}{|c|}{ No. of applications (B) } & 1.87 & 1.68 \\
\hline \multicolumn{7}{|c|}{ Interaction: (A) $\times(\mathrm{B})$} & 14.1 & 17.0 \\
\hline
\end{tabular}

Table 4. c. Leaf concentration of Manganese (ppm) in Velencia orange tree sprayed with chelated iron in both 2016 and 2017 seasons.

\begin{tabular}{lccccccccc}
\hline & \multicolumn{1}{c}{ Mn (ppm) } \\
\hline Chelated & \multicolumn{1}{c}{ T1 } & \multicolumn{1}{c}{ T2 } & \multicolumn{1}{c}{ T3 } & \multicolumn{2}{c}{ Av. } \\
\cline { 2 - 10 } iron (\%) & $\mathbf{2 0 1 6}$ & $\mathbf{2 0 1 7}$ & $\mathbf{2 0 1 6}$ & $\mathbf{2 0 1 7}$ & $\mathbf{2 0 1 6}$ & $\mathbf{2 0 1 7}$ & $\mathbf{2 0 1 6}$ & $\mathbf{2 0 1 7}$ \\
\hline Control & 9.7 & 10.1 & 10.0 & 9.8 & 11.1 & 13.0 & 10.3 & 11.0 \\
0.5 & 10.0 & 9.3 & 9.3 & 7.5 & 8.8 & 9.1 & 9.3 & 8.6 \\
0.7 & 11.1 & 9.0 & 8.8 & 9.7 & 11.0 & 10.0 & 10.3 & 9.6 \\
1.0 & 9.8 & 9.5 & 9.3 & 10.0 & 10.0 & 8.0 & 9.7 & 9.1 \\
Mean & 10.1 & 9.4 & 9.3 & 10.2 & 10.0 & 9.9 & & \\
\hline LSD (0.05): & & & & & & Ns & 1.40 \\
Levels of iron spray (A) & & & & & 2.00 & 2.00 \\
No. of applications (B) & & & & & 1.66 & 1.86 \\
Interaction: (A) $\times(\mathrm{B})$ & & & &
\end{tabular}




\section{REFERENCES}

Basiouny, F.M. and C.D. Leonard. (1970). Comparison of different iron formulations for effectiveness in correcting iron chlorosis in citrus. Florida Citrus Exp. Stn., 83: 1-6.

Boxma, R., (1972). Bicarbonate as the most important soil factor in lime-induced chlorosis in the Netherlands. Plant Soil 37, 233-243.

Chen, Y., Barak, P., (1982). Iron nutrition of plants in calcareous soils. Adv. Agron. 35, 217-240.

Chapman, H.D. (1960). Leaf and soil analysis as guides for citrus fertilizer practices in Southern California orchards. Calif. Agric., 14 (10): 13-14.

Cochran, W.C. and G.M. Cox. (1957). Experimental Design. J. Wiley and Sons, Inc., New York.

FAO. (2006). Plant nutrition for food security: A guide for integrated nutrient management. Food and Agriculture Organization of The United Nations, Rome.

Guest, P.L. and H.D. Chapman. (1949). Investigation on the use of iron sprays, dusts, and soil applications to control iron chlorosis of citrus. Proc. Amer. Soc. Hort. Sci., 54: 11-21.

Hilgeman, R.H. (1955). Correction of iron chlorosis with iron chelated in Arizona. Calif. Citr., 54: 406-428.

Huang, H., Hu, C.X., Tan, Q., Hu, X., Sun, X., Bi, L., (2012). Effects of Fe-EDDHA application on iron chlorosis of citrus trees and comparison of evaluations on nutrient balance with three approaches. Sci. Hortic. 146: 137-142.

Labanuskas, C.K., W.W. Jones, and T.W. Embleton. (1969). Low reisidue micronutrient nutritional sprays for citrus. Proc. $1^{\text {st }}$ Citr. Sycmp., Riverside, Calif., pp. $1535-1542$.

Loupassaki, M., Lionakis, S., Androulakis, I., (1997). Iron deficiency in kiwi and its correction by different methods. In: III International Symposium on Kiwifruit, Vol. 444, pp. 267-272.

Mengel, K., (1994). Iron availability in plant tissues-iron chlorosis on calcareous soils. Plant Soil 165, 275283.

Nawar, A.M. (1978). Timing of foliar application of iron, zinc, and pear trees. M. Sc. Thesis, Fac. Agric., Alex. Univ.

Primo, E., J. M. Carrasco, and P. Canat. (1970). Trace metal deficiencies in orange trees. 2- Efficiency of some Efficiency of some deficiency. Rev. agraquim. Tecral. Aliment, 10: 283-292 (cf. Hort. Absts., 41: abst. 7499).

Pestana, M., De Varennes, A., Faria, E.A., 2003. Diagnosis and correction of iron chlorosis in fruit trees: a review. J. Food Agric. Environ. 1, 46-51.
Ranker, E.R. (1972) . Determination of total nitrogen. J. Assoc. Agric. Chemists.

Saad-Alla, M.H., M.A. El-Shourbagy, M.A. El-Nokrashi, A.F. Soliman, and R.A. ElWazzan. (1981). Effect of foliar application of different micronutrients on yield and fruit quality of Valencia organe trees. Agri. Res. Rev., Egypt. 59 (3): 83-92.

Sideris, C.P. and H.Y. Young. (1946). Effect of iron on certain nitrogenous fractions of Ananas comouss (L) Merr. Plant Physiol., 21 (1): 75-94.

Smith, P.F. 1962. Mineral analysis of plant tissues. Ann. Rev. plant Physiol., 13: 81-108.

Sweidan, A.M., M.B. Barakat, and A.F.S. Nasr. (1982). Response of growth. Chlorosis and mineral content of Washington novel orange trees to different sorts of nutrients. Fac. Agric., Zagazig Univ., Res. Bull. 513, pp. $1-28$.

Srivastava, A., S., Singh,(2009). Zinc nutrition in ' Nagpur'mandarin on haplustert. J. Plant Nutr. 32, 1065-1081.

Tagliavini, M., Abadia, J., Rombola, A.D., Abadia, A., Tsipouridis, C., Marangoni, B.,(2000). Agronomic means for the control of iron deficiency chlorosis in deciduous fruit trees. J. Plant Nutr. 23, 2007-2022.

Tagliavini, M., Rombola, A.D., (2001). Iron deficiency and chlorosis in orchard and vineyard ecosystems. Eur. J. Agron. 15, 71-92.

Wallace, A. (1966). Chelated metals for supplying micronutrient of fruit crops. In. N. F. Childers (ed.) Fruit nutrition. Horticulture Publications, Rutgers Univ., New Jersey.

Wallace, A. (1971). Mineral element analysis of plants by means of an Emission spectrograph; regulation of the micronutrient status of plants by chelating agents and other factors. Univ. Calif. Los Angeles, Calif.

Wallihan, E.F. and T.W. Embleton. (1961). Iron chlorosis. Calif. Citr., 46: 67, 87, 89.

Wallihan, E.F. and M.G. Garber. (1966). How much iron is enough? Calif. Citr., 51: 450-459.

Wallihan, E.F., M.G. Garber, G.E. Goodall, R.C. Platt, and R.W. Southwick. (1954). Orchard trials with iron chelates. Calif. Citr., 40: 30-31.

Wallihan, E.F., M.G. Garber, and R.G. Sharpless. (1964). Response of chloratic citrus leaves to iron sprays in relation to stomatal apertures, proc. Amer. Soc. Hort. Sci., 85: 210-217.

Zekri, M., T. A., Obreza, (2003). Micronutrient Deficiencies in Citrus: Iron, Zinc, and Manganese. University of Florida Cooperative Extension Service, Institute of Food and Agricultural Sciences, EDIS.

Zekri, M., T.A., Obreza, (2009). Plant Nutrients for Citrus Trees. University of Florida Cooperative Extension Service, Institute of Food and Agricultural Sciences, EDIS.
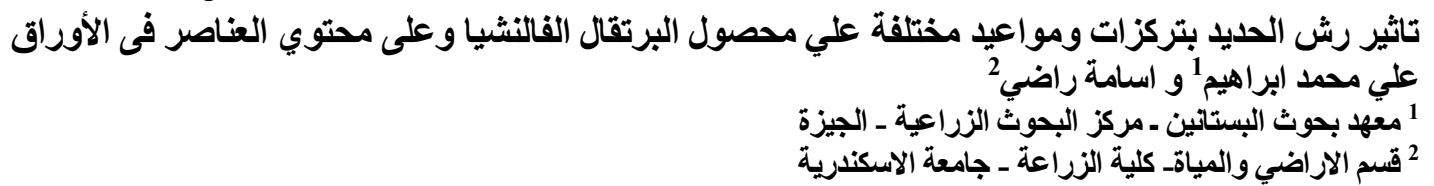

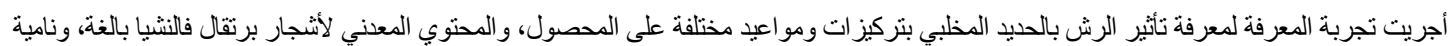

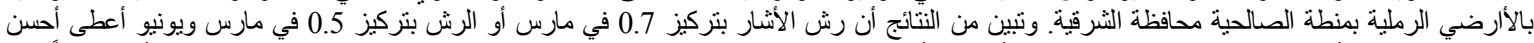

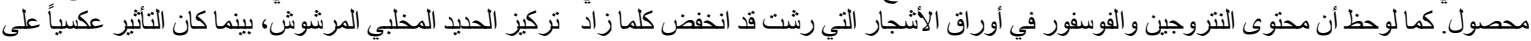

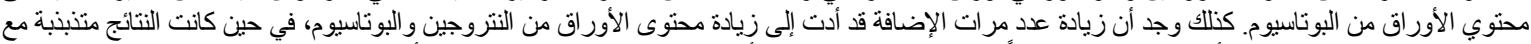

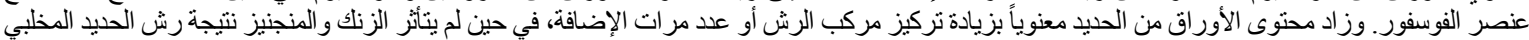
في السنة الأولى، بينما أنت نفس المعاملة إلى حدوث أنخفاض ملحوظ في السنة الثانية. 